\title{
杭頭加振実験に基づく液状化過程における 杭の水平地盤反力のメカニズム \\ MECHANISM OF HORIZONTAL SUBGRADE REACTION OF PILE DURING SOIL LIQUEFACTION BASED ON PILE TOP VIBRATION TESTS
}

\author{
田村修次*1, 小林健 一*2
}

Shuji TAMURA and Ken'ichi KOBAYASHI

\begin{abstract}
Horizontal subgrade reaction of a pile during soil liquefaction is investigated based on pile top vibration tests using a large-scale shear box. The subgrade reaction was resolved into elastic force and viscous force by back analysis using the Voigt model. It is shown that (1) the elastic force and the viscous force are independent of frequency under conditions which the displacement amplitude and the excess pore water pressure are constant; (2) as the excess pore water pressure increases, the modulus of elasticity decreases much more than the coefficient of viscosity; (3) the contribution of the elastic force to the horizontal subgrade reaction decreases with an increase in the excess pore water pressure.
\end{abstract}

Keywords: Soil liquefaction, Horizontal subgrade reaction, Pile foundation, Pile top vibration test, Elastic force, Viscous force 液状化、水平地盤反力、杭基礎、杭頭加振実験、“弾性力、粘性力

1.はじめに

杭基礎を設計するうえで、水平地盤反力の評価は重要である。その

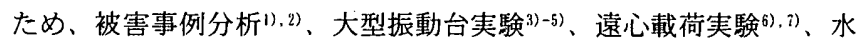

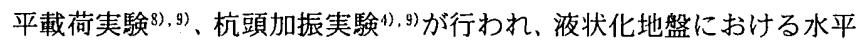
地盤反力の検証が進められている。動的な水平地盤反力は、杭と地盤 の相対変位に依存する成分（弾性力）と相対速度に依存する成分（粘 性力）の和として考えることができる。一般的に弾性力は粘性力より 大きく、地盤反力は相対变位に依存すると考えられている。そこで、 多くの既往の研究は、相対変位と地盤反力の関係 $(\mathrm{p}-\mathrm{y}$ 曲線) に着 目している。一方、“液状化地盤における水平地盤反力が、相対速度に 依存することが指摘畂れている。このことは、液状化地盤の場合、 粘性力が地盤反力に大きな影響を及ぼす可能性を示唆している。し かし、粘性力に着目した研究例は極めて少なく、粘性力の周波数依存 性や過剩間隙水圧が粘性力に及ぼす影響等、粘性力の基本的性質は 明らかでない。また、地盤反力に対する弾性力と粘性力の寄与も十分 な検討がされていない。

以上の背景から、筆者らは、杭頭加振実験で得られた水平地盤反力 を弾性力と粘性力に分離する手法を提案した"1)。さらに本研究では、 過剩間隙水圧の消散過程における杭頭加振実験に基づいて、地盤反 力に対する弾性力と粘性力の寄与、弾性力と粘性力の周波数依存性およ
び過剰間览水圧が弾性係数と粘性係数に及ぼす影響を検討する。

\section{2. 実験概要}

実験は、科学技術庁 (現:独立行政法人) 防災科学技術研究所で行つ た。図ー 1 に実験モデルを示す。せん断土慒は幅 $12 \mathrm{~m} 、$ 奥行き $3.5 \mathrm{~m}$ 、 高さ $6 \mathrm{~m}$ である。パイルキャップは幅 $2.5 \mathrm{~m} 、$ 奥行き $1.8 \mathrm{~m}$ 、高さ $0.6 \mathrm{~m}$ 、質 量1.7tonである。杭は直径 $165.2 \mathrm{~mm}$ 、肉厚 $3.7 \mathrm{~mm}$ 、長さ $5.3 \mathrm{~m} 、 \mathrm{EI}=1259 \mathrm{kNm}^{2}$ の鋼管杭 4 本とした。パイルキャップと杭頭は剛結合、杭先端はピン

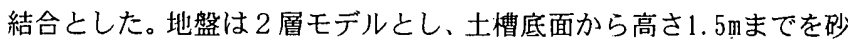

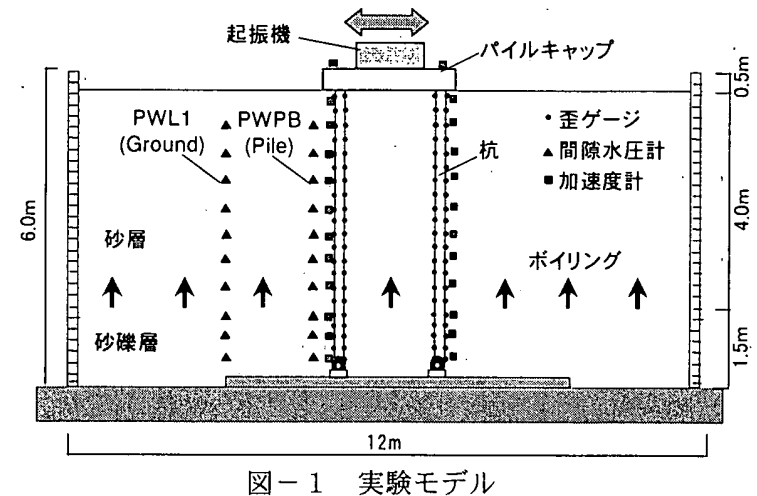

*1 信州大学工学部社会開発工学科 助教授 · 博士 (工学)

*2 北陸セキスイハイム 修士 (工学) (元 信州大学 大学院生)
Assoc. Prof., Faculty of Engineering, Shinshu University, Dr. Eng. Hokuriku Sekisui Heim Co., M. Eng.

(Former Graduate Student, Shinshu University) 
磁層、その上部を $4 m$ の飽和砂層とした。飽和砂層は霞ヶ浦砂を用い て、水中落下法で作成した。自由地盤の卓越周期から換算される飽和 砂層の $\mathrm{S}$ 波速度は $75 \mathrm{~m} / \mathrm{s}$ 程度、砂磁層の $\mathrm{S}$ 波速度は $230 \mathrm{~m} / \mathrm{s}$ 程度であ る。杭体に歪みゲージ、加速度計、間隙水圧計を設置し、杭から2m離 れた自由地盤に間隙水任計を設置した。

砂碟層上面からのボイリングで液状化を再現し、その前後で、パイ ルキャップ上に設置した起振機で杭頭加振実験を行った。加振モ一 メントは一定 $(98 \mathrm{kNm})$ 、入力波はsin波スウィープ波形とした。加振 周波数は 4 〜 $10 \mathrm{H} 2$ である。ボイリング前の加振をEx0、ボイリング直後 の加振をEx1、ボイリングから2分 30 秒後の加振をEx2、4分後の加振を Ex3とした。杭の水平地盤反力は、杭の曲げ歪みから算定した曲げ モーメントの 2 階微分で求めた。また、杭加速度の 1 階積分で杭速 度、2 階積分で杭変位を求めた。本実験では地盤が振動しないため、 杭速度が地盤と杭の相対速度、杭変位が地盤と杭の相対変位に相当 する。
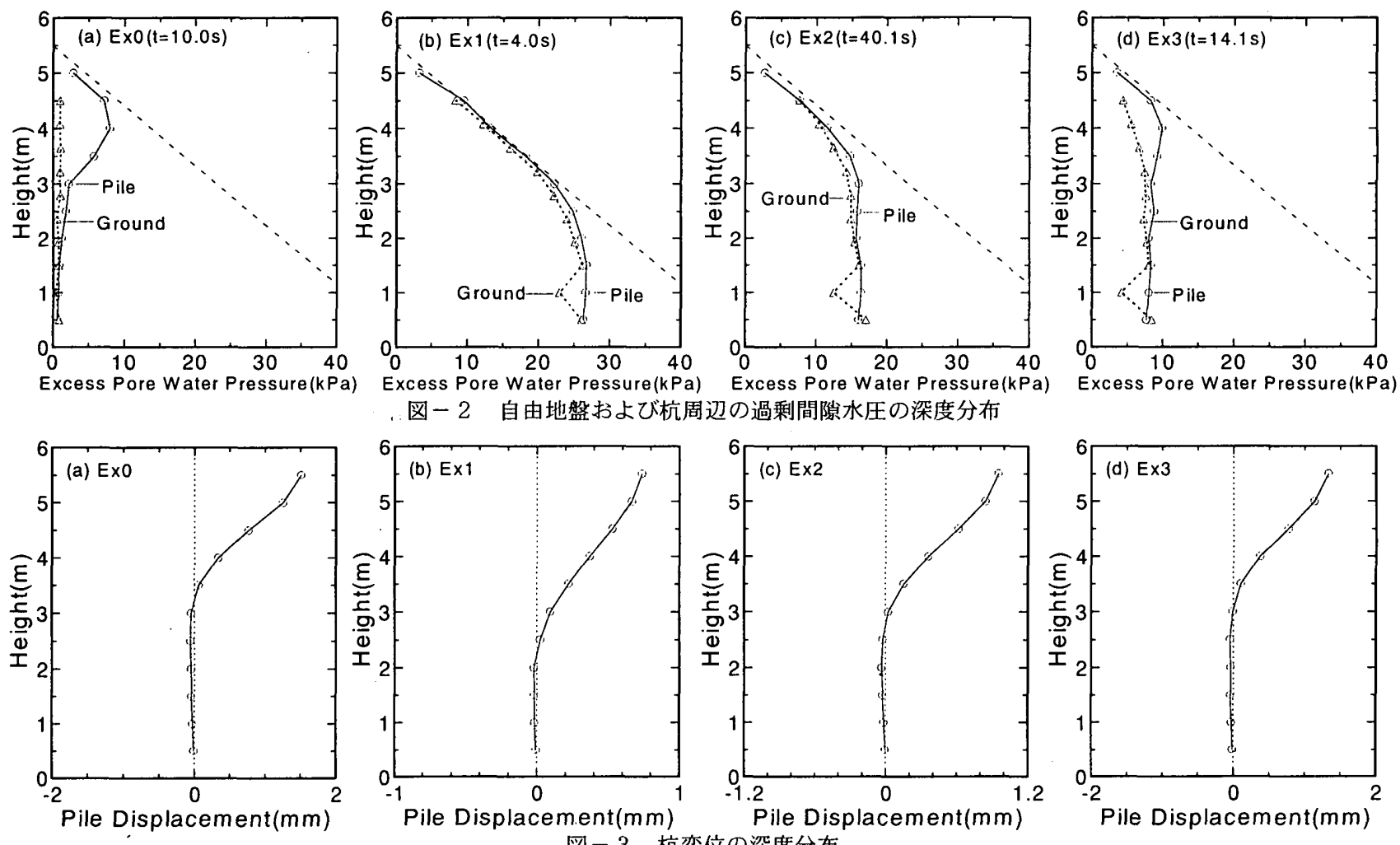

図 -3 杭変位の深度分布
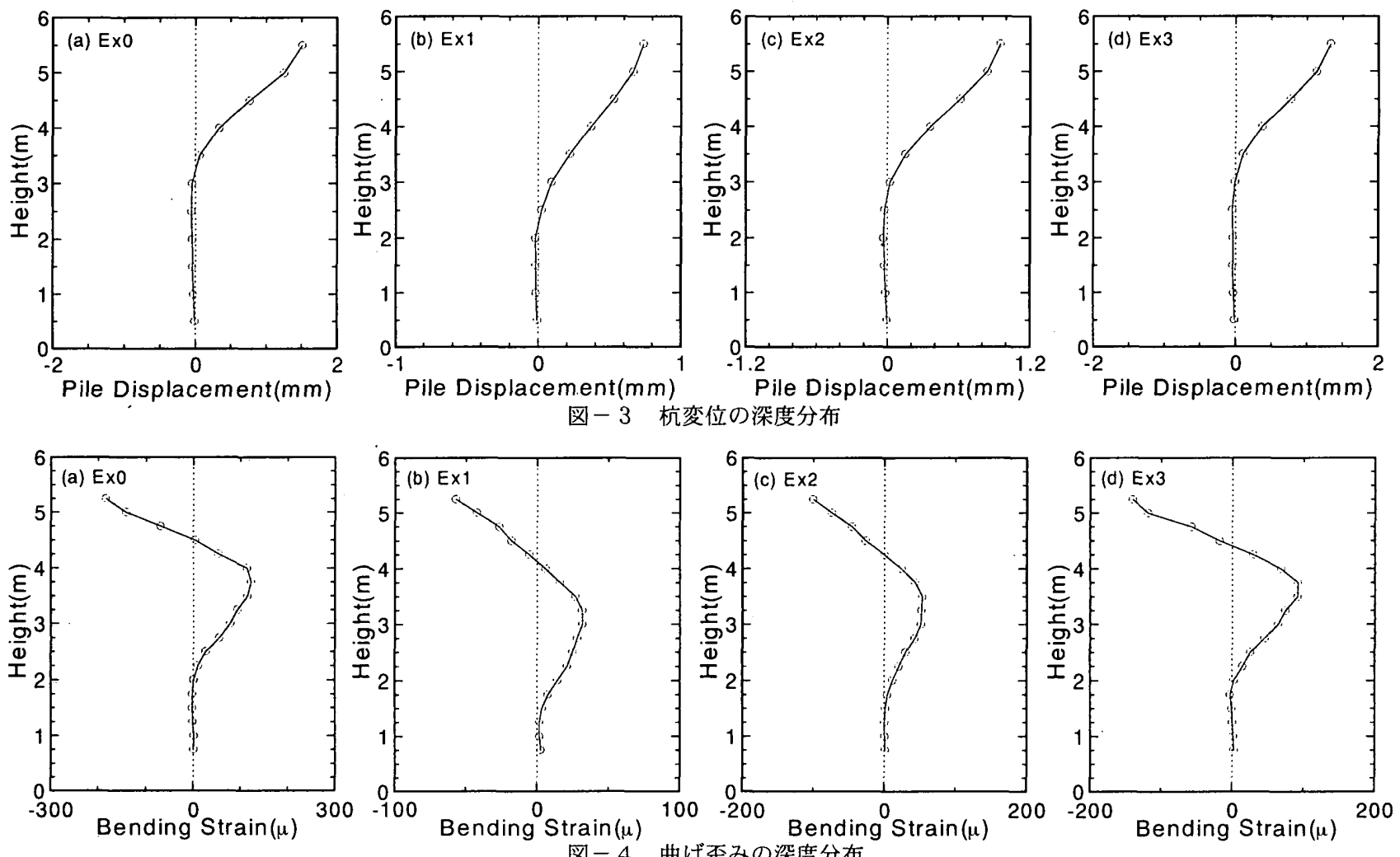

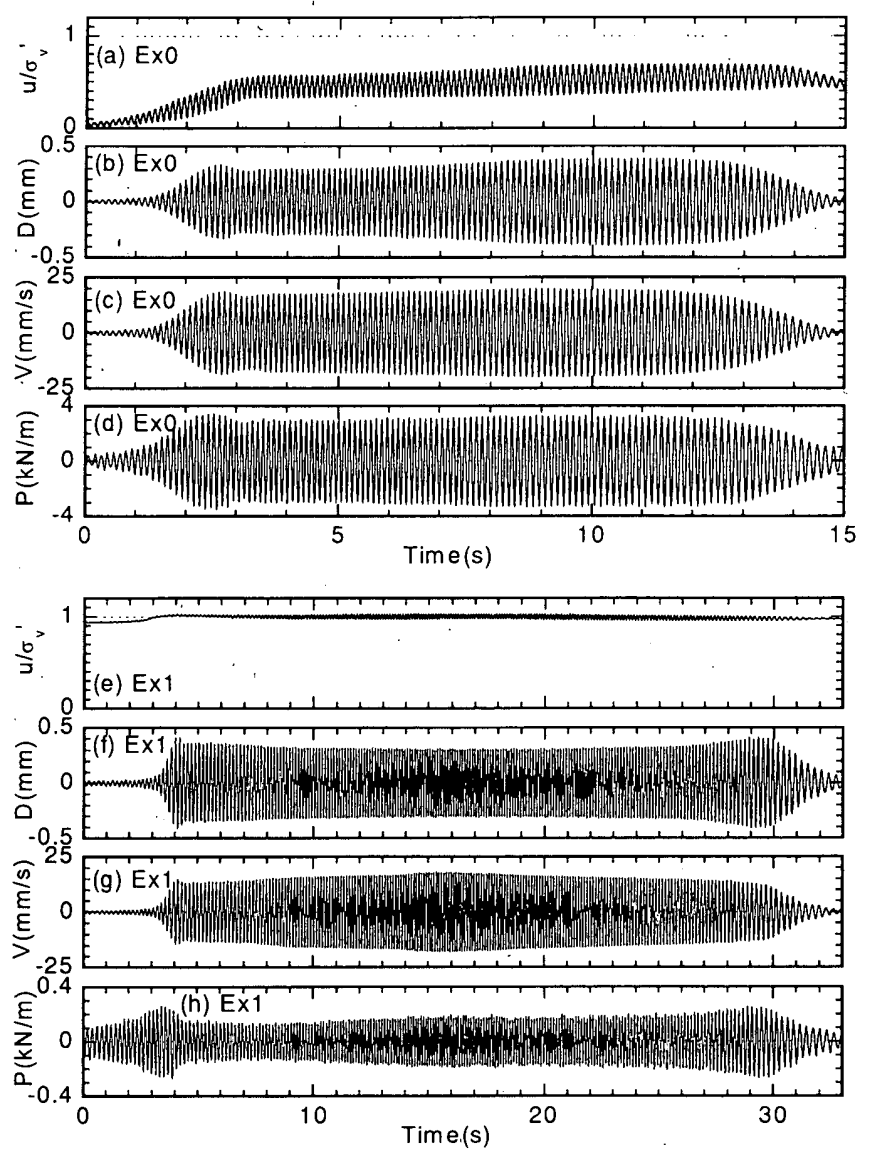

図一 5 過剩間隙水圧比、杭変位、杭速度および水平地盤反力の時刻歴（高さ $4.0 \mathrm{~m} ）$
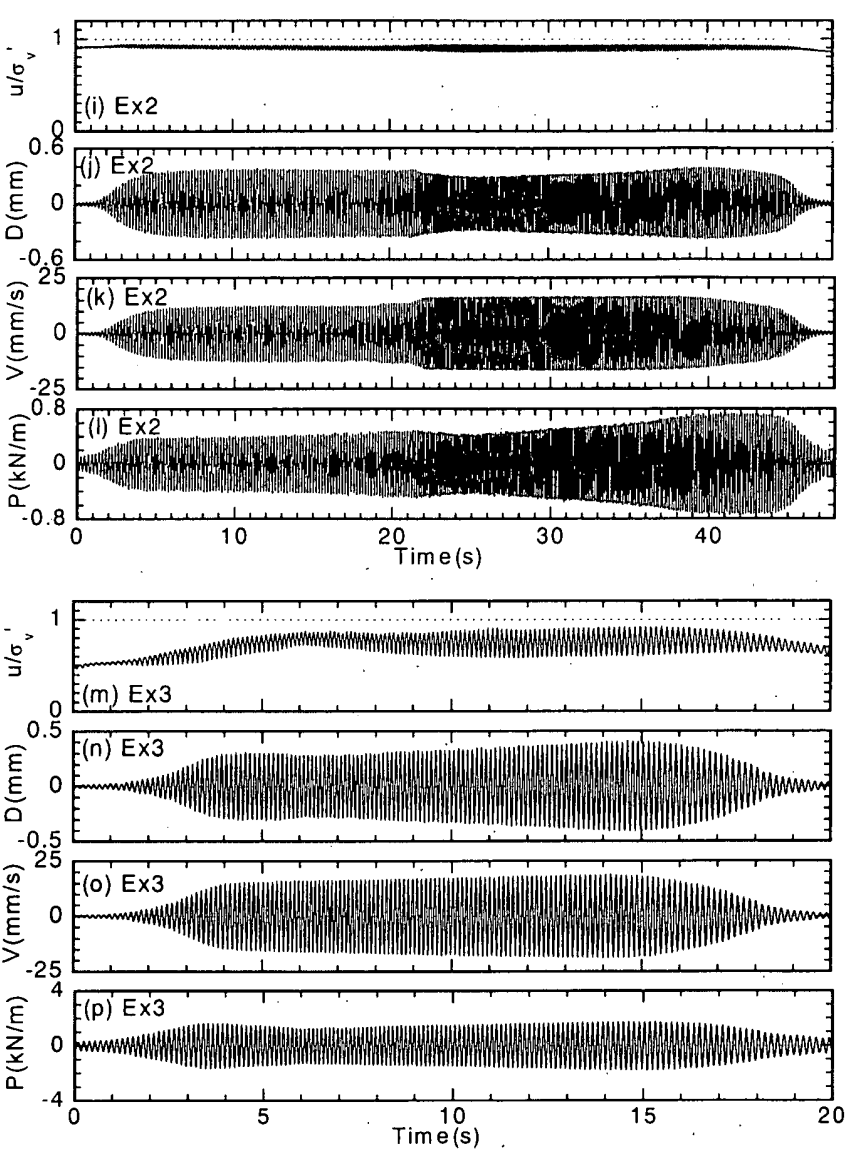

から11秒にかけて、杭変位は徐々に増加するのに対し、杭速度はほぼ 一定である。このように杭変位と杭速度で、その振幅の時間変動はや や異なる。地盤反力の時間变動は、杭変位のそれと概ね対応する。Ex 1 の場合 (図一 $5, \mathrm{e}-\mathrm{h})$ 、過剩間陌水圧比は概ね 1 であり、液状化してい ることが分かる。4〜15秒にかけて、杭変位は徐々に減少するのに対 し、杭速度は増加する。地盤反力は增加する傾向であり、その振幅の 時間変動は杭速度と概対対応する。Ex2の場合 (図 $-5, i-1)$ 、過剩間 隙水圧比は $0.85 \sim 0.95$ である。地盤反力の時問変動は加振前半で杭 速度と、加振後半で杭変位と概子対応する。Ex3の場合 (図 $-5, m-p$ )、 過剩間隙水圧比は $0.5 \sim 0.8$ である。地盤反力の時間変動は、杭変位と 概ね対応する。

\section{2 水平地盤反力と杭変位・杭速度の関係}

地盤反力之杭変位・杭速度の関倸を検討するため、図一 6 に 5 10 秒における杭変位と地盤反力の関倸および杭速度と地盤反力の関倸 を示す。Ex0の場合、杭変位と地盤反力の関係（図－6a）は、傾いた 扁平な棈円のループを描く。地盤反力のピークは杭変位のピークと 対応し、地盤反力は杭変位に概ね依存することが確認できる。一方、 杭速度と地盤反力の関係(図-6b) は、円形に近いループを描き、地 盤反力のピークは杭速度のピークと対応しない。Ex1の場合、杭変位 と地盤反力の関係(図一 $6 \mathrm{c}$ ) は、ほぼ円形のループを描く。一方、杭 速度と地盤反力の関係(図一 $6 \mathrm{~d}$ ) は、傾いた扁平な棈円のループを描 き、地盤反力のピークが杭速度のピークと対応する。すなわち、地盤 反力は杭速度に依存する。Ex2の場合、地盤反力は杭速度に概社依存 

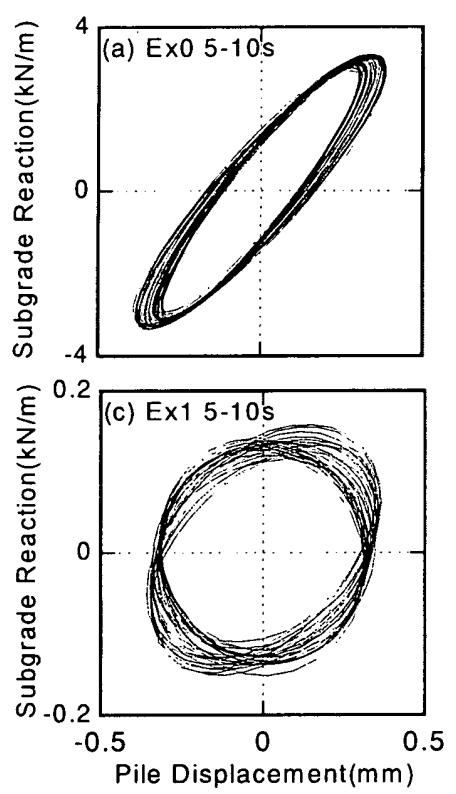
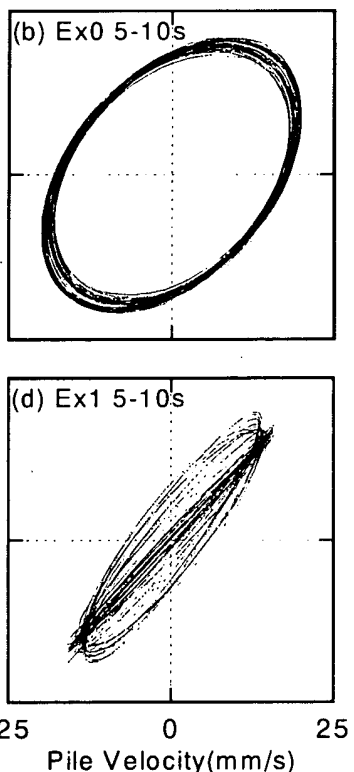
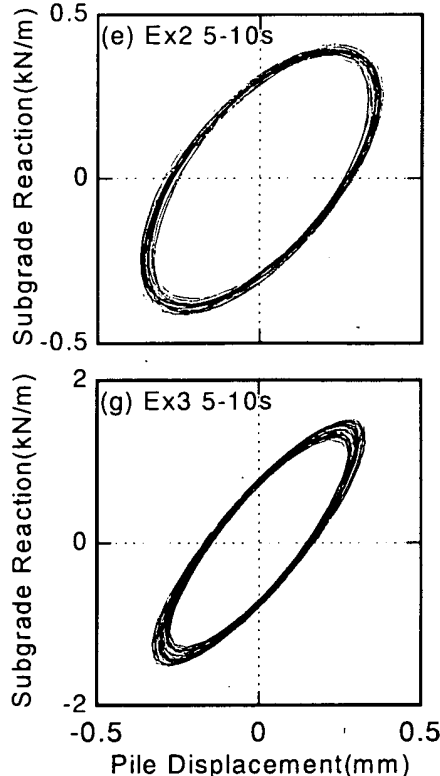

Pile Displacement $(\mathrm{mm})$
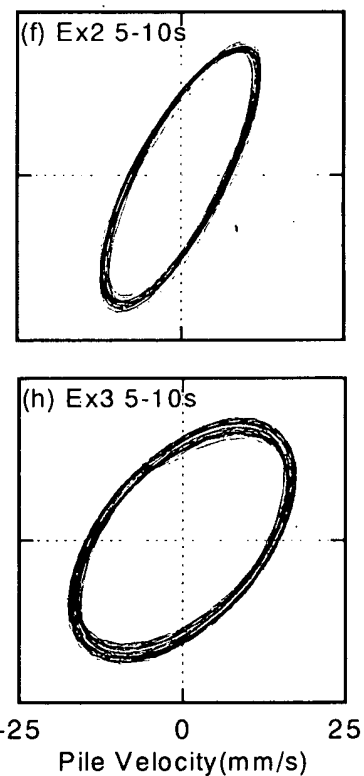

図-6 水平地盤反力と杭変位、杭速度

するのに対し、Ex3の場合、地盤反力は杭変位に概ね依存する。以上 から、地盤反力と杭変位・杭速度の関係は、過剩間隙水圧比によって 異なることが分かる。

4. 水平地盤反カの発生メカニズム

\section{1 水平地盤反力のモデル化}

水平地盤反力と杭変位・杭速度の関係をさらに検討するため、図一 7 に示すVoigtモデルで地盤反力をモデル化し、地盤反力を弾性力、 粘性力に分離する ${ }^{\prime \prime}$ 。図一 8 に、杭変位と水平地盤反力 $(\mathrm{P})$ の関係を模 式図で示す。傾いた棈円である杭変位と地盤反力の関倸は、傾いた直 線と傾きを持たない棈円に分けることができる。前者が変位依存の 地盤反力である弾性力 $\left(\mathrm{P}_{\mathrm{d}}\right)$ 、後者が速度依存の地盤反力である粘性力 $\left(P_{v}\right)$ である。Voigtモデルによると、地盤反力は次式で与えられる。

$$
P=\mu \cdot D+\mu^{\prime} \cdot \frac{d D}{d t}
$$

ここに、Dは杭変位、 $\mu$ は弾性係数、 $\mu$ ’は粘性係数である。(1)式の右 辺第 1 項が弾性力 $\mathrm{P}_{\mathrm{N}}$ 、第2項が粘性力 $\mathrm{P}_{\mathrm{v}}$ に対応する。弾性係数および粘 性係数は、次式で算定される。

$$
\begin{aligned}
\mu & =\frac{P_{1}}{D_{a}} \\
\mu^{\prime} & =\frac{P_{2}}{\omega \cdot D_{a}}
\end{aligned}
$$

ここに、 $D_{a}$ は杭変位の振幅、 $P_{1}$ は杭変位 $D_{a}$ における地盤反力、 $P_{2}$ は杭変 位ゼロにおける地盤反力、以は円振動数である。なお、本実験では加 振周波数が変化しているため、弾性係数および粘性係数を杭変位波 形の半周期ごとに算定した。

提案手法の妥当性を検討するため、式 (1)〜 (3) で地盤反力を算定し た。図ー 9 に非液状化地盤のEx0 と液状化地盤のEx1における水平地 盤反力の実験值と推定值を示す。Ex0、Ex1ともに推定值は実験値と良
Soil

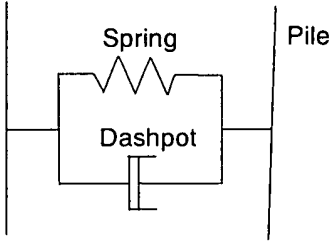

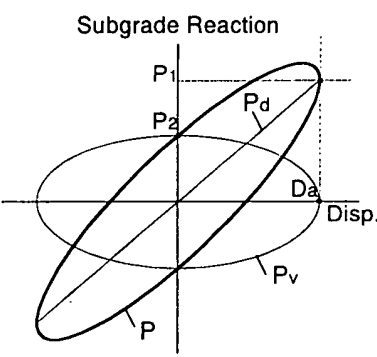

図-7 Voigtモデル 図-8 杭変位と水平地盤反力（模式図）
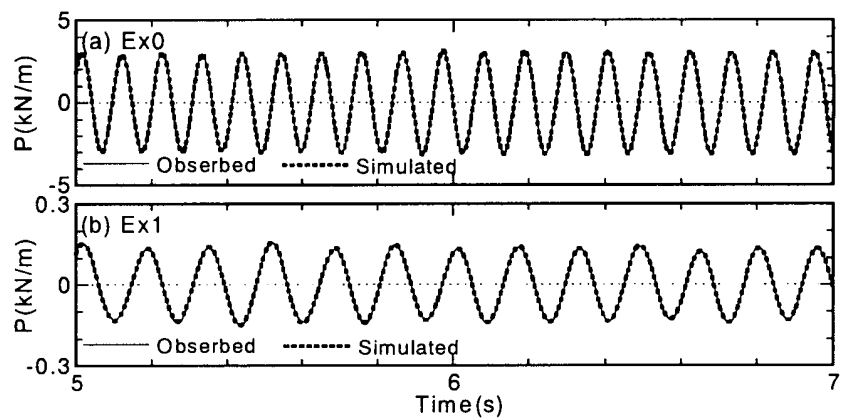

図－9 水平地盤反力の実験值と推定値

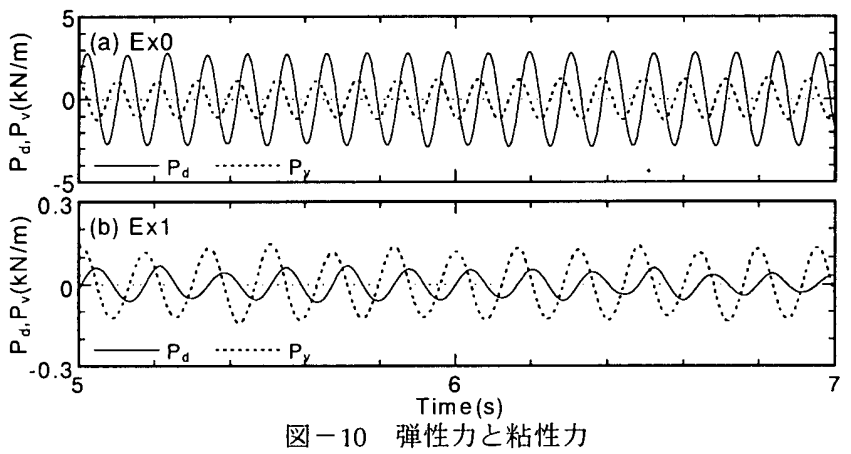



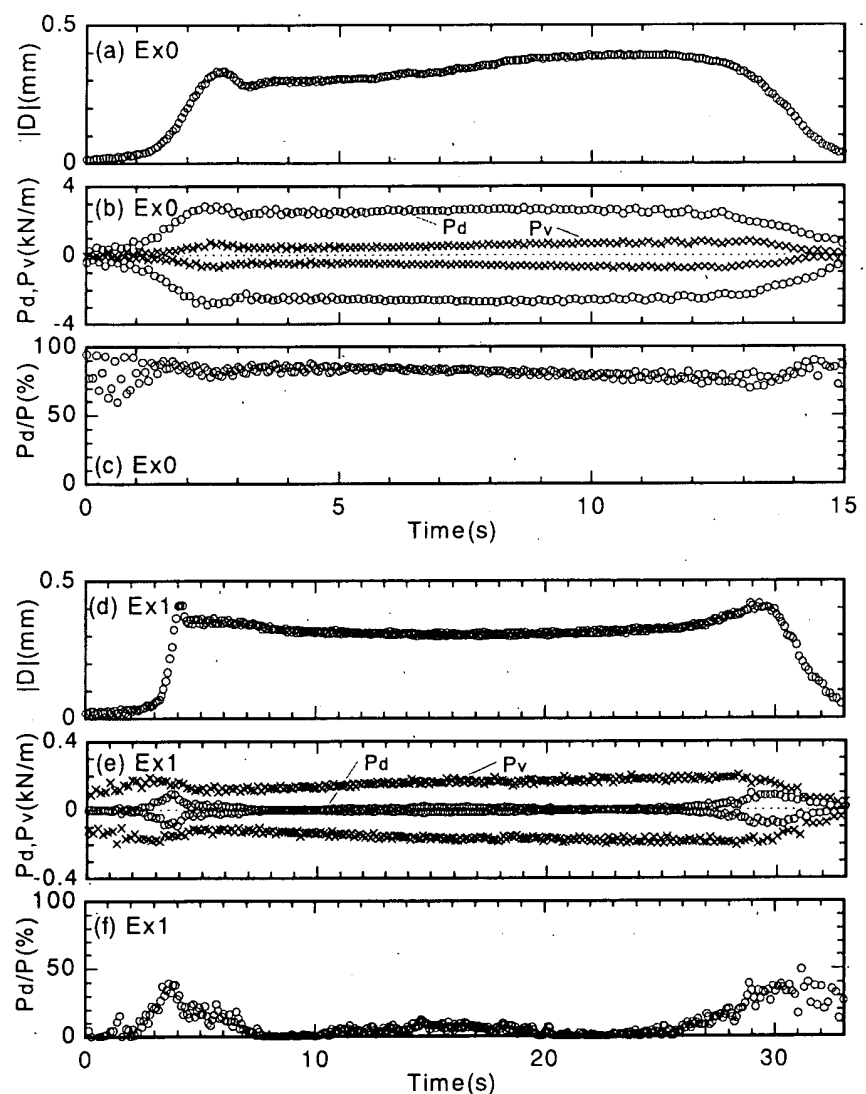

図ー11 杭変位、弾性力と粘性力、地盤反力にしめる弾性力の割合
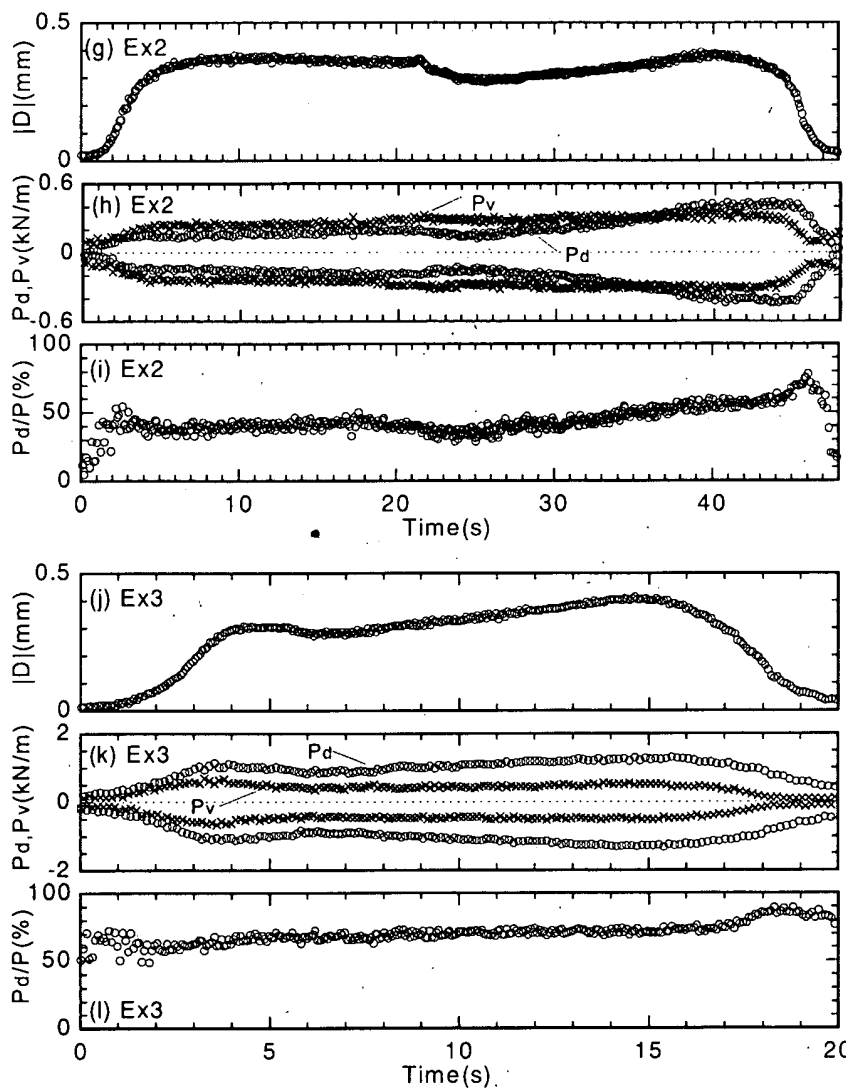
Time(s)

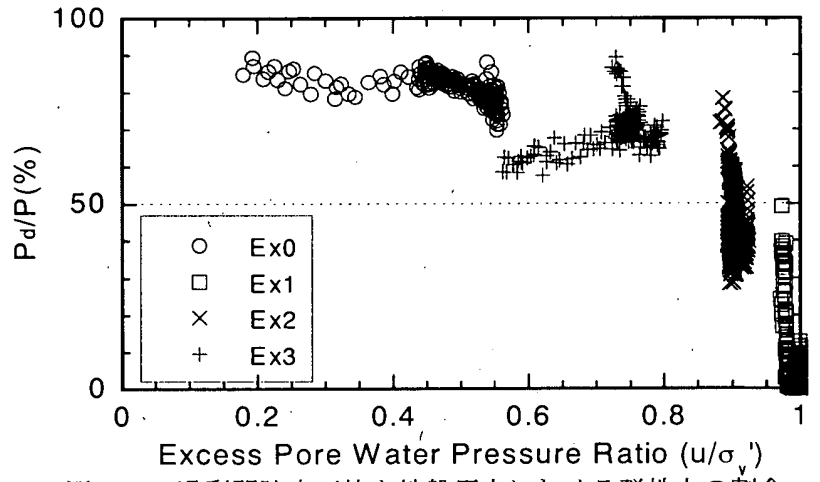

図一 12 過剩間隙水圧比と地盤反力にしめる弾性力の割合

たがって、地盤反力は杭変位に依存する。それに対し、過剩間隙水圧 比が 0.9 程度より高くなると、地盤反力にしめる弾性力の割合が急激 に低下して50\%以下になる。さらに液状化が進行し、過剩間隙水圧比 がほぼ1になると、地盤反力にしめる弾性力の割合は数程度になり、 地盤反力は杭速度に依存することが分かる。

\section{3 弾性力および粘性力の周波数依存性}

弾性力の周波数依存性を検討するため、図一 13 に杭振動数と弾性 力振幅の関係を示す。なお、杭変位、過㮃間隙水圧の変動は弾性力に 影響を及ぼすため、杭変位振幅が概ね一定 $( \pm 0.02 \mathrm{~mm})$ かつ過剩間隙水 圧比が概ね一定（士0.01）の区間を用いた。弾性力の大きさは、加振 ケースによって異なる。ただし、同じ加振ケースでは、地盤反力は振 動数によらず概ね一定である。すなわち、過剩間隙水圧比が一定の条 

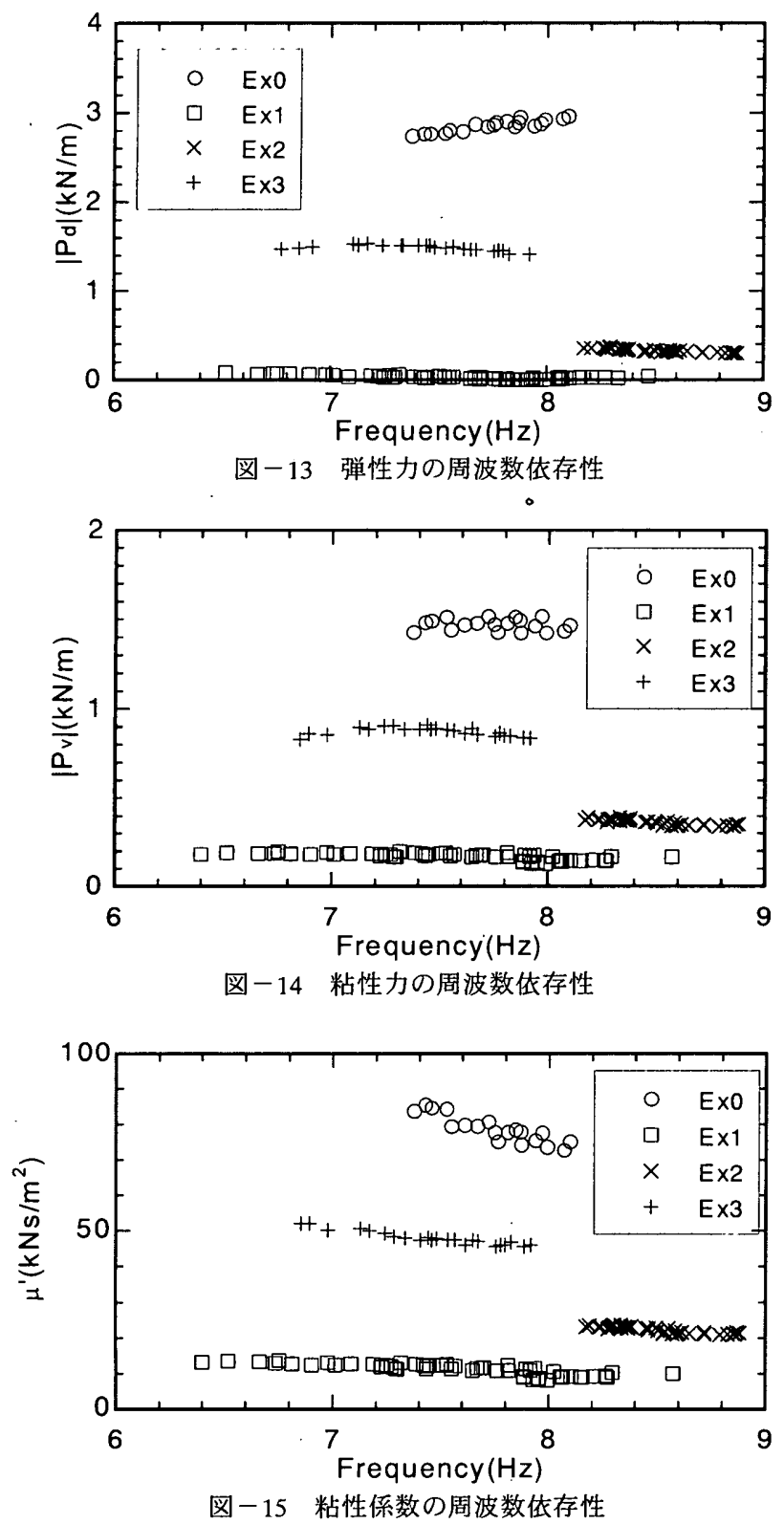

件では、弾性力の周波数依存性は小さい。なお、杭変位および弾性力 が一定であるため、弾性係数も (1) 式右辺第 1 項から振動数によらず 一定と考えられる。

粘性力の周波数依存性を検討するため、図一14に杭振動数と粘性 力振幅の関係を示す。なお、弾性力のケースと同様、杭変位および過 剩間隙水圧比が概ね一定の区間を用いている。どの加振ケースも、粘 性力は振動数によらず概ね一定であり、粘性力の周波数依存性は小 さい。さらに検討を進めるために、図ー15に杭振動数と粘性係数の関 係を示す。どの加振ケースも、振動数が増加すると粘性係数が減少す ることが分かる。すなわち、杭変位振幅が一定で杭振動数が増加する と杭速度も增加するものの、粘性係数が減少したため、(1) 式右辺第 2 項から粘性力は概ね一定になったと考えられる。以上のように、弾 性力、粘性力ともに周波数依存性は認められなかった。ただし、本研 究で検討した周波数帯は限られており、今後、さらに検討が必要之考 えられる。
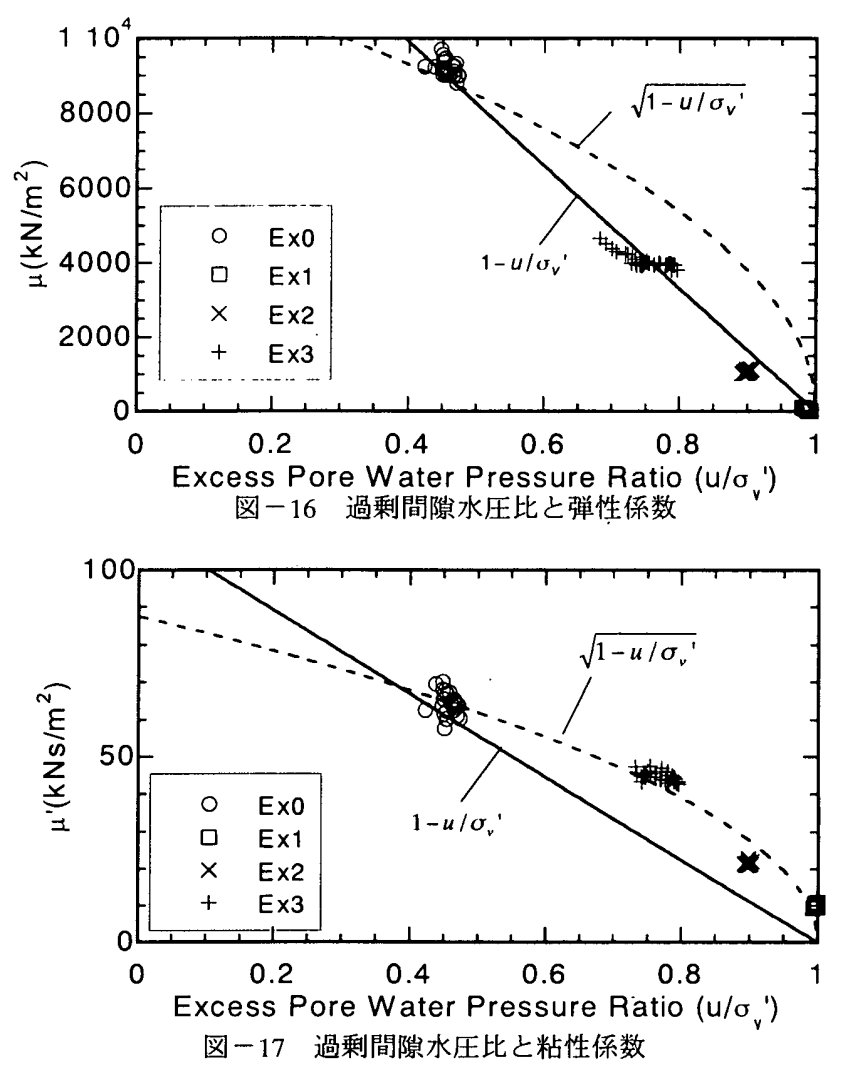

4.4 過剩間隙水圧比が弾性係数、粘性係数に及ほす影響

過剩間隙水圧比が地盤反力の発生メカニズムに及ぼす影響を検討 するため、図一16に過剩間隙水圧比之弾性係数の関係を示す。なお、 杭変位の変動は弾性係数に影響を及ぼすため、どの加振ケースも、杭 変位振幅 $0.28 \sim 0.32 \mathrm{~mm}$ の範囲を対象にした。過剩間隙水圧の増加に 伴って弾性係数が減少していることが分かる。低减係数 $\mathrm{r}_{\mathrm{d}}$ (4) 式お よび(5)式とし、それぞれ実線および破線で図中に示す。

$$
\begin{aligned}
& r_{d}=1-u / \sigma_{v}^{\prime} \\
& r_{d}=\sqrt{1-u / \sigma_{v}^{\prime}}
\end{aligned}
$$

弾性係数と過剩間隙水圧比の関係は (4) 式と概ね対応が良い。すなわ ち、弾性係数は概称有効応力比 $\left(1-\mathrm{u} / \mathrm{\sigma}_{\mathrm{y}}^{\prime}{ }^{\prime}\right)$ に比例することが分かる。

さらに検討を進めるため、図ー17に過剩間隙水圧比と粘性係数の 関倸を示す。杭変位と杭振動数の変動が粘性倸数に影響を及ぼすた め、どの加振ケースも、杭変位は $0.28 \sim 0.32 \mathrm{~mm}$ 、杭振動数は8.5〜 9. $5 \mathrm{~Hz}$ の籁囲を対象にした。巣性係数のケースと同様に過剩間隙水圧 の増加に伴い、粘性係数が減少していることが分かる。過剩間隙水圧 比と粘性係数の関係は (5) 式と概ね対応が良い。したがって、粘性倸 数は概ね有効応力比の平方根 $\left(1-\mathrm{u} / \mathrm{\sigma}_{\mathrm{v}}{ }^{\prime}\right)^{0.5}$ に比例することが分かる。 以上のように、過㮃間吵水玨が上昇すると、弾性係数、粘性係数とも に低下する。ただし、粘性係数の低下率が弾性係数のそれに比べて小 さいため、相対的に地盤反力にしめる粘性力の割合が大きくなった と考えられる。

\section{5. まとめ}

過剩間隙水圧の消散過程において実大スケールの杭頭加振実験を 
行い、得ら扎た水平地盤反力を弾性力と粘性力に分離し、地盤反力に 対する弾性力と粘性力の寄与を検討した。さらに、弾性力と粘性力の周 波数依存性および過㮃間隙水圧が弾性係数と粘性係数に及ぼす影響を検 討し、以下の結果を得た。

（1）過剩間隙水圧比が 0.9 程度より高くなると、地盤反力にしめる弾性 力の割合が急激に低下して50\%以下になる。さらに液状化が進行し、 過剩間隙水庄比がほほ1になると、地盤反力にしめる弾性力の割合は 数\%程度になり、地盤反力は相対速度に依存する。

(2)杭変位振幅および過剩間隙水圧比が一定の場合、振動数が增加す ると粘性係数は減少し、粘性力は周波数によらずほぼ一定になる。一 方、弾性係数および弾性力の周波数依存性は小さい。

(3)過剩間隙水圧が増加すると、弹性係数は概ね有効応力比 $\left(1-u / \sigma_{v}{ }^{\prime}\right)$ に比例して減少する。それに対し、粘性係数は概子有効応力比の平方 根 $\left(1-\mathrm{u} / \mathrm{\sigma}_{\mathrm{v}}{ }^{\prime}\right)^{0.5}$ に比例して減少する。過剩間隙水圧が上昇すると、粘 性係数の低下率が弾性係数のそれに比べて小さいため、地盤反力に しめる粘性力の割合が大きくなる。

なお、本研究の結果は、限られた実験条件のものであり、地盤の相 対密度、杭変位、加振周波数等によって、水平地盤反力の発生メ力二 ズムが本研究結果と異なる可能性がある。より定量的な評価をする ためには、さらに実験データの蓄積が必要と考えられる。

\section{謝辞}

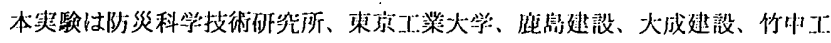

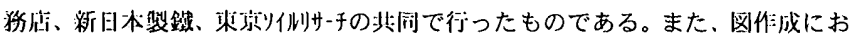

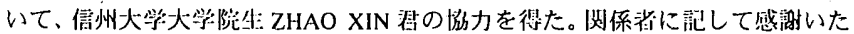
します。

\section{参考文献}

1) Fujii, S., Isemoto, N., Satou, Y., Kaneko, O., Funahara, H., Arai, T. and Tokimatsu, K. : Investigation and Analysis of a Pile Foundation Damaged by Liquefaction during the 1995 Hyogoken-Nambu Earthquake, Soils and Foundations, Special Issue on Geotechnical Aspects of the 1995 Hyogoken Nambu Earthquake, No. 2, pp. $179-192,1998.9$

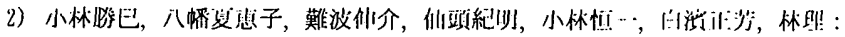

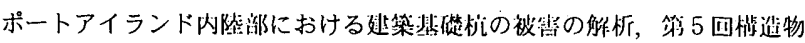
と地盤の動们相当作用シンポジウム，日本建筑学会，pp.187-192, 1998.5

3) Kagawa, T., L.M. Kraft: Lateral Pile Response during Earthquake, Journal of the Geotechnical Engineering Division, ASCE, pp.1713-1731, 1981.12

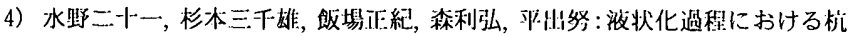

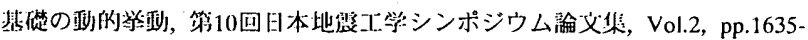
1640, 1998. 11

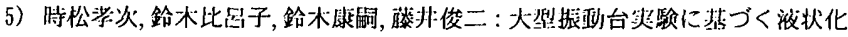

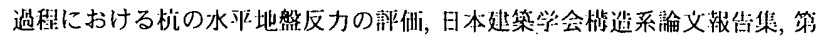
553 学, pp.57-64, 2002. 5

6) Miyamoto, Y., Miura, K., Scott, R. F. and Hushmand, B.: Pile Foundation Response in Liquefiable Soil Deposit during Strong Earthquakes, 日术建築学:会檴造系淪文 報告集, 第439号, pp.49-63, 1992.9

7) Sato, M., Shamoto, Y. and Zhang, J. -M. : Soil Pile-structure during Liquefaction on Centrifuge, Proc., 3rd Inter. Conf. on Rec. Adv. in Geotech. Earthq̣. Engrg \& Soil Dyn., 1, pp. 135-142, 1995

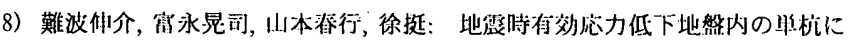

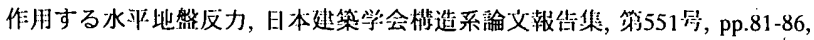
2002. 1

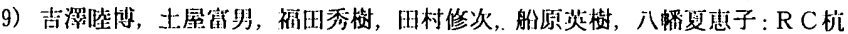

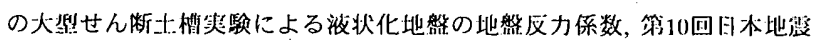
T..等シンポジウム論文集, Vol.1, pp.43-48, 1998. 11

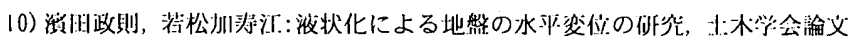
萑, No.596/III -43, pp.189-208, 1998.6

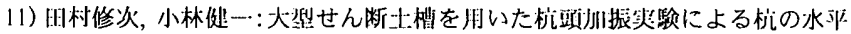

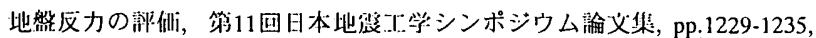
2002.11

（2003年 6 月10日原稿受理，2003年12月16日採用決定） 